\section{La Révolution française}

Cahiers de l'Institut d'histoire de la Révolution française

$11 \mid 2016$

L'Irlande et la France à l'époque de la République atlantique

\title{
Avant propos / Foreword: Writing the history of the revolutionary 1790s during the "Troubles": historiographical and moral dilemmas
}

Thomas Bartlett

\section{(2) OpenEdition}

\section{Journals}

Electronic version

URL: http://journals.openedition.org//rf/1624

DOI: $10.4000 /$ Irf. 1624

ISSN: 2105-2557

Publisher

IHMC - Institut d'histoire moderne et contemporaine (UMR 8066)

Printed version

Date of publication: 1 December 2016

\section{Electronic reference}

Thomas Bartlett, "Avant propos / Foreword: Writing the history of the revolutionary 1790s during the "Troubles": historiographical and moral dilemmas ", La Révolution française [Online], 11 | 2016, Online since 01 December 2016, connection on 03 May 2019. URL : http://journals.openedition.org//rf/1624 ; DOI : $10.4000 /$ Irf.1624

This text was automatically generated on 3 May 2019.

(c) La Révolution française 


\title{
Avant propos / Foreword: Writing the history of the revolutionary 1790s during the "Troubles": historiographical and moral dilemmas
}

\author{
Thomas Bartlett
}

1 Until the publication in 1983 of Marianne Elliott's Partners in Revolution: the United Irishmen and France 1793-1815 (Yale University Press, New Haven, Conn., 1983), it is fair to say that historical writing on Ireland and France was rather slim. The major writers, l'Abbé Geoghegan in the eighteenth, and J.C. O'Callaghan, Mathew O'Conor and J.P. Lambert in the nineteenth century, did produce lengthy volumes but their researches were confined almost exclusively to the Irish soldiers who fought in French service, largely in the period 1690 to $1790^{1}$. By and large they ignored the period of the Revolution and Empire, 1793-1815. Moreover, their concerns were rather different to those of more recent historians in that they were determined, first, to show that Voltaire's infamous gibe that the Irish made splendid soldiers abroad, but that they were militarily hopeless at home - was a grotesque and unfounded calumny, and then, to demonstrate that for bravery, steadfastness and loyalty (both to the Catholic Church and to the Stuart cause), the Irish soldier was second to none. All of these writers were Irish nationalists who regarded the Irish soldier in French service (and in the ranks of other European armies) as a sort of proto-nation overseas For that reason, they comprehensively ignored the much more numerous Irish soldiers in British service throughout the late eighteenth and the entire nineteenth centuries. With Richard Hayes, writing in the 1920s and 1930s, it is a rather different story. Hayes was a medical doctor, IRA volunteer 1916-1922, member of the Irish parliament, and later, film censor in the Irish Free State. He appears to have spent lengthy periods in the French archives, not just in the military archives at Vincennes but in French provincial archives as well. The outcome of his researches was a 
series of books and articles on individual Irishmen in France during the ancien régime and the revolutionary and Napoleonic periods. Hayes was not a trained historian and there are a number of shortcomings to his published work, notably his frequent failure to give sources for many of his assertions, views and judgements. For all that his work is still valuable. Hayes's work has to an extent been extended in the excellent The Irish Sword, a journal begun in 1949, still going strong and one that is devoted to Irish military history. While its remit is much wider than the Irish in French service or indeed in continental service, it has published numerous articles on the Irish during the revolutionary and Napoleonic period. Other aspects of Franco-Irish relations have attracted the attention of Irish historians; in this regard Louis Cullen's pioneering work on trade links in the eighteenth century, and on the Irish in the brandy trade, Eamon ó Ciosáin's articles on the Irish in west France in the early modern period and Mary Ann Lyons' book on sixteenth-century Franco-Irish relations should all be noted ${ }^{2}$.

2 However, for all that had been written about the Irish in France, it was the publication of Elliott's Partners in Revolution in 1983 that put the historiography of Franco-Irish relations on a completely new footing. The book became an instant classic and in its scope, breadth, depth, and archival reach it has never been superseded. Over thirty years since its publication, is there anything yet to say on the topic of Ireland and France during the revolutionary and Napoleonic period? There is, of course. It is in the nature of history and historical enquiry that new questions are constantly being posed, new sources uncovered, and new interpretations offered on old topics. The chapters in this volume show that. There is, however, another point to be made: it has been said that all history writing, no matter how remote the period in question, is to a greater or lesser extent, contemporary history, in so far as the concerns, the issues, and the problems in play during a historian's career will influence if not determine what they find meaningful or significant in the documents they uncover or even how they address the evidence under review. Elliott's book was researched, written and published during 'the Troubles' in Northern Ireland, at a time when republicanism was associated with murder, mayhem, car bombs and sectarian killings. Her 'take' on her sources cannot but have been influenced by the daily reports of death and destruction emanating from her native Belfast. And not just Elliott: every historian writing on Irish history during the late twentieth century had to agonise over their treatment of insurgency, insurrection, republicanism and armed rebellion. For many, there was a fear that sympathy for, say, the republican project of Theobald Wolfe Tone, would be seen as advocacy for it, that a dispassionate view of Irish republicans in the 1790s might encourage Irish republicans in the 1970s. Equally, that to dismiss republicans in the 1790s as naïve, idealistic, uninformed about Irish life, and prone to self-deception would bring consolation to unionists in the late twentieth century. This was a dilemma for historians during the Northern Ireland 'Troubles', one that has to a large extent been resolved by the ending of the Troubles in the late 1990s. But there are other contemporary 'Troubles' elsewhere that will continue to preoccupy historians and pose moral difficulties for them. The attacks on Charlie Hebdo, at the Bataclan, and in Nice (and elsewhere) will make dispassion, calmness and cool-headedness among historians studying, say, the Vendée or the Terror seem like excusing or even justifying religious fanaticism or 'terrorism'. The dilemma for the historian can never be resolved. Confronting the challenges posed by contemporary preoccupations through following the historical evidence wherever it leads may help blunt that dilemma, but cannot remove it. 


\section{NOTES}

1. For a brief discussion of these writers, see my 'Ormuzd abroad ... Ahriman at home: some early historians of the 'Wild Geese' in France, 1840-1950' in Jane Conroy (ed), Franco-Irish connections, Four Courts Press, Dublin, 2009, p. 15-30

2. L. M. Cullen, The Brandy Trade under the Ancien Régime, Cambridge, Cambridge University Press, 1998; Eamon ÓCiosáin, 'The Irish in France, 1660-90; the point of no return' in Thomas O'Connor and Mary Ann Lyons (ed), Irish communities in early modern Europe, Four Courts Press, Dublin, 2006; Mary Ann Lyons, Franco-Irish relations, 1550-1610: Politics, trade and migration, Woodbridge, Suffolk, 2003.

\section{AUTHOR}

\section{THOMAS BARTLETT}

Aberdeen University

Royal Irish Academy 